\title{
Perhitungan Reduksi Emisi Gas Buang Melalui Penentuan Rute Distribusi Beras di Kota Bandung
}

\section{Exhaust Emission Reduction Calculation Through Determination of Rice Distribution Routes di Bandung City}

\author{
MUCHAMMAD FAUZI*, DERYL BAHARUDIN SOPANDI, DAN VERANI HARTATI \\ Program Studi Teknik Industri, Widyatama University \\ Jalan Cikutra No. 204A Bandung Indonesia \\ Email : muchammad.fauzi@widyatama.ac.id
}

\begin{abstract}
Total transport energy use and carbon emissions in 2030 are estimated to be about $80 \%$ higher than at present. West Java's transportation sector emissions are projected to occupy the third position in the third-largest contributor to GRK emissions, amounting to 21.9 million tons of $\mathrm{CO}_{2}$. The West Java Provincial Government aims to reduce 3.18 million tons of $\mathrm{CO}_{2}$ eq for the energy sector and 1.1 million tons of $\mathrm{CO}_{2}$ eq for the transportation sector. Of course, this is a challenge for the government because the volume of truck logistic systems continues to increase, especially in Bandung. The purpose of this study is to determine the value of truck exhaust emissions produced and to know what strategies should be taken to reduce exhaust emissions based on the selection of distribution routes for rice distribution in Bandung City. This study uses an ILP model with a Matlab solver that compares the total mileage, the number of vehicles, and total transportation costs in two distribution systems, namely direct delivery and shared delivery. In this study, the scenario of the transport capacity was changed according to the use of the truck type fuso tub, changing the type of truck that has a larger capacity, and calculating the value of exhaust emissions for trucks in both new scenarios and two distribution systems. The results showed, to reduce exhaust emissions by adjusting the number of vehicles and the minimum total mileage through increased transport capacity and sharing delivery systems, this strategy can reduce exhaust emissions by 21.92\% for each composition.
\end{abstract}

Keywords: transportation, rice distribution, sharing delivery, emission reduction, exhaust emission

\begin{abstract}
ABSTRAK
Total penggunaan energi transportasi dan emisi karbon pada tahun 2030 diperkirakan menjadi sekitar $80 \%$ lebih tinggi daripada kondisi saat ini. Pada emisi sektor transportasi Jawa Barat diproyeksikan pada tahun 2020 menempati posisi ketiga terbesar penyumbang emisi GRK sebesar 21,9 juta ton $\mathrm{CO}_{2}$. Pemerintah Provinsi Jawa Barat memiliki target menurunkan 3,18 juta ton $\mathrm{CO}_{2}$-eq untuk sektor energi dan 1,1 juta ton $\mathrm{CO}_{2}$-eq untuk sektor transportasi. Tentu hal ini menjadi tantangan pemerintah karena faktanya pada sistem logistik volume kendaraan truk terus meningkat khususnya di Kota Bandung. Tujuan dari penelitian ini adalah untuk mengetahui nilai emisi gas buang kendaraan truk yang dihasilkan dan mengetahui strategi apa yang harus diambil untuk menurunkan emisi gas buang berdasarkan pemilihan rute distribusi untuk distribusi beras di Kota Bandung. Penelitian ini menggunakan model ILP dengan solver Matlab yang membandingkan total jarak tempuh, jumlah kendaraan, dan total biaya transportasi pada dua sistem distribusi yaitu pengiriman langsung dan pengiriman berbagi. Pada penelitian ini skenario kapasitas angkut diubah sesuai dengan penggunaan armada angkut truk jenis fuso bak, mengubah jenis truk yang memiliki kapasitas lebih besar, serta menghitung nilai emisi gas buang untuk kendaraan truk pada kedua skenario baru dan dua sistem distribusi. Hasil penelitian menunjukkan, dengan mengatur jumlah kendaraan dan total jarak tempuh minimum melalui peningkatan kapasitas angkut dan penggunaan sistem pengiriman berbagi, dapat menurunkan emisi gas buang sebesar $21,92 \%$ untuk setiap komposisinya.
\end{abstract}

Kata kunci: transportasi, distribusi beras, pengiriman berbagi, reduksi emisi, emisi gas buang, 


\section{PENDAHULUAN}

\subsection{Latar Belakang}

Kegiatan transportasi diperkirakan akan tumbuh terus selama beberapa dekade ke depan, kecuali bila ada perubahan besar pada pola penggunaan energi saat ini. Penggunaan energi untuk transportasi dunia diproyeksikan meningkat pada laju sekitar $2 \%$ per tahun, dengan tingkat pertumbuhan tertinggi terjadi di negara-negara berkembang. Total penggunaan energi untuk transportasi dan emisi karbon pada tahun 2030 diperkirakan menjadi sekitar 80\% lebih tinggi daripada kondisi saat ini(1). Untuk menurunkan emisi karbon tersebut, Pemerintah Indonesia melalui Undang-Undang Nomor 16 Tahun 2016 tentang Pengesahan Paris Agreement to The United Nations Framework Convention on Climate Change (Persetujuan Paris Atas Konvensi Kerangka Kerja Perserikatan Bangsa-Bangsa Mengenai Perubahan Iklim) menargetkan pengurangan emisi sebesar $29 \%$ dengan upaya sendiri dan menjadi $41 \%$ jika ada kerja sama internasional dari kondisi tanpa ada aksi (business as usual) pada tahun 2030, yang akan dicapai antara lain melalui sektor kehutanan, energi termasuk transportasi, limbah, proses industri, dan penggunaan produk, dan pertanian ${ }^{(2)}$. Polusi udara telah menjadi perhatian yang berkembang, terutama di kota-kota dengan ekonomi berkembang pesat, mengingat infrastruktur, populasi kendaraan, dan berkurangnya ruang hijau. Bahan bakar fosil dan transportasi adalah sumber utama partikel pencemar seperti sulfur oksida dan nitrous yang dilepaskan ke atmosfer(3)

Pulau Jawa dan Bali merupakan tulang punggung kegiatan ekonomi dan sekaligus pusat permintaan energi di Indonesia(4). Pada tahun 2010, Provinsi Jawa Barat dan Jawa Timur merupakan kontributor emisi gas rumah kaca terbesar berturut-turut sebesar 11,89 juta ton dan 10,63 juta ton setara $\mathrm{CO}_{2}$-eq. Nilai emisi yang dihasilkan di dua provinsi tersebut melampaui produksi total emisi di Pulau Sumatra. Sebagaimana diketahui, wilayah Banten dan Jawa Barat memiliki jumlah industri terbanyak di Indonesia, hal ini dikarenakan kedua wilayah tersebut merupakan daerah penyokong kebutuhan dan aktivitas ekonomi di Jakarta. Di tahun 2020, diperkirakan jumlah emisi di provinsi Jawa Barat akan naik secara drastis karena pertumbuhan sektor industri di Jawa Barat tumbuh sangat pesat yang mengakibatkan konsumsi energi yang terus naik. Pada emisi sektor transportasi Jawa Barat diproyeksikan pada tahun 2020 menempati posisi ketiga terbesar penyumbang emisi GRK sebesar 21,9 juta ton $\mathrm{CO}_{2}$ seperti yang ditunjukkan Gambar 1 .

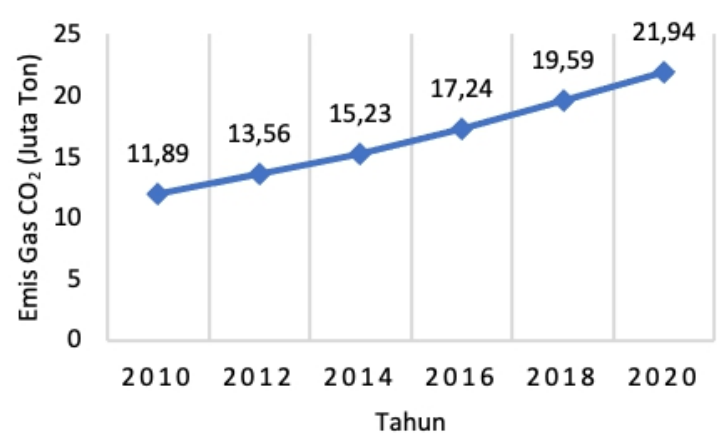

Gambar 1. Proyeksi emisi GRK (setara $\mathrm{CO}_{2}$ ) dari sektor transportasi di Jawa Barat $^{(4)}$

Peningkatan emisi GRK dari sektor transportasi di Jawa Barat menjadi perhatian pemerintah untuk membuat kebijakan dalam rangka penurunan emisi GRK melalui Peraturan Gubernur Jawa Barat Nomor 56 Tahun 2012 tentang Rencana Aksi Daerah Penurunan Emisi Gas Rumah Kaca di Jawa Barat melalui bidang-bidang pertanian, kehutanan, energi transportasi, industri, dan persampahan dengan target 3,18 juta ton $\mathrm{CO}_{2-}$ eq untuk sektor energi dan 1,1 juta ton $\mathrm{CO}_{2}$-eq untuk sektor transportasi(5). Tentu hal ini menjadi tantangan pemerintah karena faktanya pada sistem logistik volume kendaraan truk terus meningkat khususnya di Kota Bandung seperti yang ditunjukkan Gambar 2. Sejalan dengan rekomendasi penerapan green logistics yaitu penerapan strategis, teknik, dan operasional logistik yang efisien, salah satunya adalah rute distribusi yang efisien ${ }^{(6)}$. Pemilihan rute yang efisien dapat berdampak pada penghematan energi bahan bakar dan emisi gas yang dihasilkan.

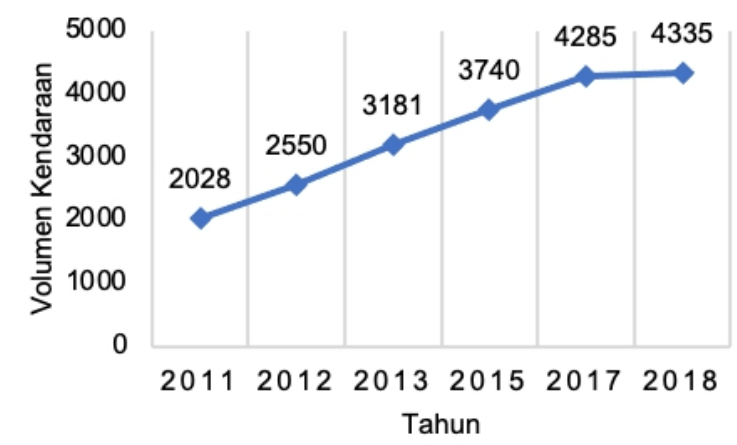

Gambar 2. Pertumbuhan volume truk Kota Bandung ${ }^{(7)}$

Berdasarkan Gambar 2 pertumbuhan volume truk di Kota Bandung terus meningkat dengan rata-rata pertumbuhan $16 \%$ setiap tahunnya. Pertumbuhan volume truk menunjukkan peningkatan produktivitas angkutan barang di Kota Bandung, namun hal 
tersebut menimbulkan permasalahan baru yaitu gas buang yang dihasilkan truk akan semakin meningkat. Salah satu komposisi gas buang yang paling berbahaya bagi kesehatan dan lingkungan adalah $\mathrm{HC}$ (Hidrokarbon) ${ }^{(8)}$. HC merupakan sumber energi listrik dan panas utama di dunia karena energi yang dihasilkan oleh hasil pembakaran. Pembakaran yang tidak sempurna dapat menyebabkan kerusakan atau pencemaran lingkungan karena bersifat racun ${ }^{(9)}$.
Salah satu aktivitas penggunaan angkutan barang truk adalah distribusi beras pada Pasar Induk Caringin Kota Bandung. Kegiatan distribusi tersebut, setiap harinya mencakup 28 tujuan pasar tradisional yang menggunakan 40 rute, dengan total panjang perjalanan 627,6 $\mathrm{km} /$ hari $^{(10)}$ dengan nilai beban emisi gas buang yang dihasilkan selama satu tahun ditunjukkan pada Tabel 1

Tabel 1. Nilai beban emisi gas buang

\begin{tabular}{ccccccc}
\hline $\begin{array}{c}\text { Parameter } \\
\text { Gas Buang }\end{array}$ & $\begin{array}{c}\mathrm{CO} \\
\text { (ton/tahun) }\end{array}$ & $\begin{array}{c}\mathrm{HC} \\
\text { (ton/tahun) }\end{array}$ & $\begin{array}{c}\text { NOx } \\
\text { (ton/tahun) }\end{array}$ & $\begin{array}{c}\mathbf{P M 1 0} \\
\text { (ton/tahun) }\end{array}$ & $\begin{array}{c}\mathbf{C O}_{2} \\
\text { (ton/tahun BBM) }\end{array}$ & $\begin{array}{c}\mathbf{S O}_{2} \\
\text { (ton/tahun) }\end{array}$ \\
\hline $\begin{array}{c}\text { Nilai Beban } \\
\text { Emisi Gas }\end{array}$ & 1,924 & 0,412 & 4,055 & 0,321 & 726,623 & 0,188 \\
\hline
\end{tabular}

Tentunya angka tersebut menyumbang peran dalam pencemaran udara di Indonesia khususnya Kota Bandung. Gas CO dapat mengakibatkan turunnya berat janin dan meningkatnya jumlah kematian bayi serta kerusakan otak, gas $\mathrm{HC}$ dapat menimbulkan infeksi paru-paru, gas NOx dapat menyebabkan gangguan pada syaraf, $\mathrm{PM}_{10}$ dapat mempengaruhi reaksi radang paru-paru, gas $\mathrm{CO}_{2}$ dapat merusak lapisan ozon bumi serta CFC, halons, karbon tetra klorida, dan gas klorin dapat menipiskan lapisan ozon. Bahaya gas $\mathrm{SO}_{2}$ yang utama adalah hujan asam dan dapat menganggu sistem pernafasan(11). Untuk menurunkan beban emisi gas tersebut maka diperlukan strategi yang efektif. Salah satu kunci efektif dalam penerapan supply chain management adalah menerapkan strategi jaringan distribusi dan transportasi yang baik. Peran jaringan distribusi dan transportasi sangat vital bagi perusahaan. Kemampuan perusahaan untuk mengirimkan produk ke konsumen secara tepat waktu dan akurat menentukan kesuksesan sebuah produk di pasaran ${ }^{(12)}$.

\subsection{Tujuan Penelitian}

Tujuan dari penelitian ini adalah untuk mengetahui nilai emisi gas buang yang dihasilkan kendaraan truk dan mengetahui strategi apa yang harus diambil untuk menurunkan emisi gas buang berdasarkan pemilihan rute distribusi beras di Kota Bandung yang optimal. Diharapkan hasil penelitian ini dapat menjadi bahan kajian berbagai pihak untuk lebih peduli terhadap lingkungan dan strategi pengambilan keputusan transporter di Indonesia khususnya di Kota Bandung.

\section{Bahan dan Metode}

Penelitian ini menggunakan penelitian terdahulu sebagai parameter awal pada rute distribusi beras di Pasar Induk Caringin(10), untuk solver menggunakan Matlab(13), dan beban emisi gas buang menggunakan pendekatan Peraturan Menteri Negara Lingkungan Hidup Nomor 12 Tahun 2012 ${ }^{(14)}$. Metode solusi dari penelitian terdahulu adalah model ILP menggunakan solver Matlab yang membandingkan total jarak tempuh (km), jumlah kendaraan yang digunakan, dan total biaya transportasi per tahun pada dua sistem distribusi yaitu pengiriman langsung dan pengiriman berbagi(13). Pada penelitian ini skenario kapasitas angkut diubah sesuai dengan penggunaan armada angkut truk jenis fuso bak dengan ukuran karoseri panjang 550 $\mathrm{cm}$, lebar $220 \mathrm{~cm}$, tinggi $220 \mathrm{~cm}$, dan berat maksimal angkut 8 ton, mengubah jenis truk yang memiliki kapasitas lebih besar yaitu 9 ton, serta menghitung nilai emisi gas buang untuk kendaraan truk pada kedua skenario baru dan dua sistem distribusi yang dibahas oleh penelitian terdahulu(10). Tahapan penelitian digambarkan seperti Gambar 3.

Berikut adalah perhitungan kapasitas angkut yang digunakan pada penelitian ini:

Skenario 1, kapasitasi di maksimalkan 8 ton.

$\mathrm{P}^{\prime}=$ Panjang karoseri/Panjang karung beras

$\mathrm{P}^{\prime}=550 \mathrm{~cm} / 75 \mathrm{~cm}=7,3 \sim 7$ karung beras

$\mathrm{L}^{\prime}=$ Lebar karoseri/Lebar karung beras

$\mathrm{L}^{\prime}=220 \mathrm{~cm} / 45 \mathrm{~cm}=4,8 \sim 4$ karung beras

$\mathrm{T}^{\prime}=$ Tinggi karoseri/Tinggi karung beras

$\mathrm{T}^{\prime}=220 \mathrm{~cm} / 45 \mathrm{~cm}=14,7 \sim 14$ karung beras

Kapasitas angkut $=P^{\prime} \times L^{\prime} \times T^{\prime}$

Kapasitas angkut $=7 \times 4 \times 14=392$ karung beras/truk

Total berat angkut $=392$ karung beras/truk $\times 50$ $\mathrm{kg} / \mathrm{karung}$ beras

Total berat angkut $=19.600 \mathrm{~kg} / \mathrm{truk}$ 


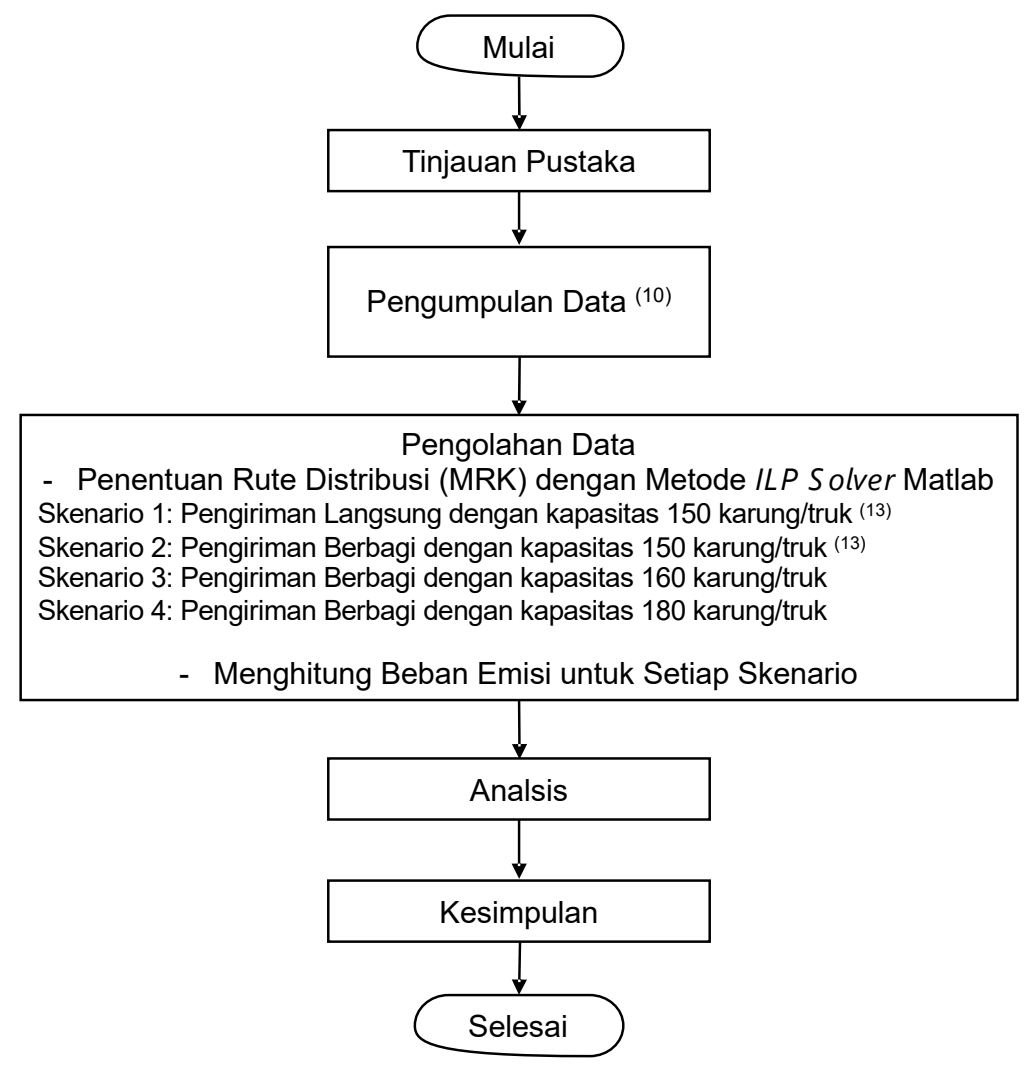

Gambar 3. Alur penelitian

Karena total berat angkut melebihi maksimal angkut $8.000 \mathrm{~kg}$, maka perhitungan angkutnya menggunakan formula berikut:

Kapasitas angkut $=$ Berat maksimal

angkut/Berat karung beras isi

Kapasitas angkut $=8.000 \mathrm{~kg} / \mathrm{truk} / 50$

$\mathrm{kg} / \mathrm{karung}$

Kapasitas angkut $=160$ karung beras/truk

Skenario 2, mengganti jenis truk dengan kapasitas maksimal 9 ton

Kapasitas angkut $=$ Berat maksimal angkut/Berat karung beras isi

Kapasitas angkut $=9.000 \mathrm{~kg} / \mathrm{truk} / 50$

$\mathrm{kg} / \mathrm{karung}$

Kapasitas angkut $=180$ karung beras/truk

\subsection{Konsep Green Logistics}

Green Logistics adalah disiplin ilmu yang berkaitan dengan pengadaan, penyimpanan, dan penghantaran barang sesuai dengan jenis, jumlah, waktu, dan tempat yang dikehendaki konsumen dari titik asal ke titik tujuan dengan penekanan tidak merusak lingkungan. Aktivitas green logistics misalnya pengurangan GRK, minimalisasi limbah, penggunaan bahan baku ramah lingkungan, pemanfaatan kembali limbah atau sampah dengan daur ulang (3R: Reduce, Reuse, Recycle), pemanfataan ilmu dan teknologi untuk penghematan energi, dan emisi karbon dipandang menjadi masalah dunia karena menjadi salah satu penyebab perubahan ilkim. Kontribusi sektor logistik sekitar $13,1 \%$. Untuk mengurangi emisi karbon, konsep green logistics menjadi terkemuka untuk menuju keberlanjutan. Proses distribusi memiliki pengaruh yang cukup besar terhadap lingkungan ${ }^{(15)}$. Strategi jangka pendek dan panjang green distribution yang ditunjukkan pada Tabel 2 dan 3 .

Tabel 2. Strategi jangka pendek green distribution ${ }^{(15)}$

\begin{tabular}{cl}
\hline No & \multicolumn{1}{c}{ Strategi Jangka Pendek } \\
\hline 1 & Pengawasan lingkungan harus diterapkan pada aktivitas sehari-hari \\
2 & Melakukan analisis siklus hidup untuk menentukan dampak lingkungan \\
3 & Mengembangkan program untuk meninjau dan mengamati kinerja lingkungan \\
4 & Membuat umpan balik dari kelompok lokal tentang masalah lingkungan dan sosial \\
5 & Penggunaan energi dan material harus diperhitungkan \\
6 & Fokus pada kinerja buruk terhadap aktivitas lingkungan \\
7 & Menerapkan kriteria dan prinsip lingkungan pada strategi transportasi dan pembelian \\
8 & Mengembangkan program pengelola bahan berbahaya bagi lingkungan \\
9 & Membuat program pelatihan pendidikan tingkat tinggi tentang lingkungan \\
\hline
\end{tabular}


Tabel 3. Strategi jangka panjang green distribution ${ }^{(15)}$

\begin{tabular}{cl}
\hline No & \multicolumn{1}{c}{ Strategi Jangka Panjang } \\
\hline 1 & Semua kegiatan masa depan harus menggunakan analisis efek lingkungan \\
2 & Jaringan tranportasi harus dikembangkan untuk kesadaran akan perkembangan \\
3 & Mengembangkan rencana untuk menurunkan biaya pemeliharaan melalui prosedur, \\
& pelatihan, dan pendidikan pengemudi \\
4 & Penghematan finansial harus dilakukan melalui penggunaan bahan bakar yang efisien \\
5 & Membangun hubungan baik dengan pemangku kepentingan internal dan eksternal \\
\hline
\end{tabular}

\subsection{Konsep Model Transportasi}

Transportasi adalah pemindahan manusia atau barang dengan menggunakan wahana yang digerakan oleh manusia atau mesin(16). Transportasi adalah usaha memindahkan, menggerakkan, mengangkut, atau mengalihkan suatu objek dari suatu tempat ke tempat lain, di mana di tempat lain ini objek tersebut lebih bermanfaat atau dapat berguna untuk tujuantujuan tertentu(17). Untuk meningkatkan kinerja transportasi salah satunya adalah penentuan rute distribusi yang menghasilkan jarak terpendek untuk menghasilkan waktu pengiriman tercepat dan biaya pengiriman termurah. Untuk menghasilkan rute optimal dapat menggunakan pendekatan MRK (Masalah Rute Kendaraan) terkait dengan penentuan set rute yang optimal untuk dilakukan oleh armada kendaraan untuk melayani set pelanggan tertentu. Solusi MRK terkait dengan penentuan serangkaian rute, masing-masing dilakukan oleh satu kendaraan yang dimulai dan berakhir di depot masingmasing, sehingga semua persyaratan pelanggan terpenuhi, semua kendala operasional terpenuhi, dan ongkos transportasi global diminimalkan ${ }^{(10)}$.

\subsection{Konsep Pencemaran Udara (Emisi Gas Buang)}

Menurut Undang-Undang Nomor 32 Tahun 2009 tentang Perlindungan dan Pengelolaan Lingkungan Hidup, Pencemaran lingkungan hidup adalah masuk atau dimasukkannya makhluk hidup, zat, energi, dan/atau komponen lain ke dalam lingkungan hidup oleh kegiatan manusia sehingga melampaui baku mutu lingkungan hidup yang telah ditetapkan ${ }^{(18)}$. Kriteria baku kerusakan lingkungan hidup adalah ukuran batas perubahan sifat fisik, kimia, dan/atau hayati lingkungan hidup yang dapat ditenggang oleh lingkungan hidup untuk dapat tetap melestarikan fungsinya. Salah satu pencemaran lingkungan adalah gas-gas beracun yang dihasilkan oleh pembakaran bahan bakar kendaraan (emisi). Komposisi gas buang yang merupakan hasil pembakaran adalah air $\left(\mathrm{H}_{2} \mathrm{O}\right)$, karbon monoksida (CO), hidrokarbon $(\mathrm{HC})$, nitrogen oksida $\left(\mathrm{NO}_{x}\right)$, partikulat 10 mikron $\left(\mathrm{PM}_{10}\right)$, karbon dioksida $\left(\mathrm{CO}_{2}\right)$, dan sulfur dioksida $\left(\mathrm{SO}_{2}\right)$.

Saat ini indeks standar kualitas yang digunakan secara resmi di Indonesia adalah ISPU (Indeks Standar Pencemaran Udara) sesuai dengan Keputusan Menteri Negara Lingkungan Hidup Nomor P.14/MENLHK/SETJEN/KUM.1/7/2020 tentang Indeks Standar Pencemaran Udara ${ }^{(19)}$. Manfaat dari ISPU adalah sebagai bahan informasi kepada masyarakat tentang kualitas udara ambien di lokasi dan waktu tertentu serta sebagai bahan pertimbangan pemerintah pusat dan daerah dalam melaksanakan pengelolaan dan pengendalian pencemaran udara ${ }^{(20)}$. ISPU ditetapkan dengan cara mengubah kadar pencemaran udara yang terukur menjadi suatu angka yang tidak berdimensi. Rentang ISPU ditunjukkan pada Tabel 4.

Tabel 4.Rentang Indeks Standar Pencemaran Udara (ISPU) ${ }^{(19)}$

\begin{tabular}{ccl}
\hline Kategori & Rentang & \multicolumn{1}{c}{ Penjelasan } \\
\hline Baik & $0-50$ & $\begin{array}{l}\text { Tingkat kualitas udara yang tidak memberikan efek bagi kesehatan } \\
\text { manusia atau hewan dan tidak berpengaruh pada tumbuhan, bangunan } \\
\text { atau nilai estetika }\end{array}$ \\
\hline Sedang & $51-100$ & $\begin{array}{l}\text { Tingkat kualitas udara yang tidak berpengaruh pada kesehatan manusia } \\
\text { maupun hewan tetapi berpengaruh pada tumbuhan yang sensitif, dan nilai } \\
\text { estetika }\end{array}$ \\
\hline Tidak Sehat & $101-199$ & $\begin{array}{l}\text { Tingkat kualitas udara yang bersifat merugikan pada manusia ataupun } \\
\text { kelompok hewan yang sensitif atau bisa menimbulkan kerusakan pada } \\
\text { tumbuhan ataupun nilai estetika }\end{array}$ \\
\hline $\begin{array}{c}\text { Sangat Tidak } \\
\text { Sehat }\end{array}$ & $200-299$ & $\begin{array}{l}\text { Tingkat kualitas udara yang dapat merugikan kesehatan pada sejumlah } \\
\text { segmen populasi yang terpapar }\end{array}$ \\
\hline Berbahaya & $300-$ lebih & $\begin{array}{l}\text { Tingkat kualitas udara berbahaya yang secara umum dapat merugikan } \\
\text { kesehatan yang serius }\end{array}$ \\
\hline
\end{tabular}

\subsection{Beban Emisi}

Beban pencemaran udara yang dihasilkan kendaraan dinyatakan melalui panjang perjalanan seluruh kendaraan, volume kendaraan, dan faktor emisi. Sehingga formulasi perhitungan beban emisi dari kendaraan bermotor adalah sebagai berikut( ${ }^{(19)}$ : 
$E=f \times V K T \times F_{e} \times 10^{-6}$

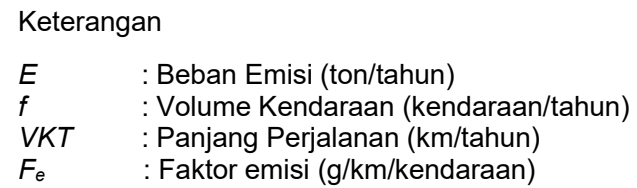

Pada penelitian ini analisis perhitungan beban pencemaran udara dari kendaraan bermotor menggunakan pendekatan berdasarkan Peraturan Menteri LH Nomor 12 Tahun 2012 tentang Pelaksanaan Pengendalian Pencemaran Udara di daerah ${ }^{(14)}$. Faktor emisi gas buang kendaraan untuk kota metropolitan dan besar di Indonesia berdasarkan kategori kendaraan truk ditunjukkan pada Tabel 5.

Tabel 5. Nilai faktor emisi gas buang kendaraan(14)

\begin{tabular}{lcccccc}
\hline $\begin{array}{c}\text { Parameter } \\
\text { Gas Buang }\end{array}$ & $\begin{array}{c}\mathrm{CO} \\
(\mathbf{g} / \mathbf{k m})\end{array}$ & $\begin{array}{c}\mathrm{HC} \\
(\mathbf{g} / \mathbf{k m})\end{array}$ & $\begin{array}{c}\mathrm{NOx} \\
(\mathbf{g} / \mathbf{k m})\end{array}$ & $\begin{array}{c}\mathbf{P M 1 0} \\
(\mathbf{g} / \mathbf{k m})\end{array}$ & $\begin{array}{c}\mathbf{C O}_{2} \\
(\mathbf{g} / \mathbf{k m} \mathbf{~ B B M})\end{array}$ & $\begin{array}{c}\mathbf{S O}_{2} \\
(\mathbf{g} / \mathbf{k m})\end{array}$ \\
\hline Faktor Emisi & 8,4 & 1,8 & 17,7 & 1,4 & 3172 & 0,82 \\
\hline
\end{tabular}

Faktor emisi (Fe) merupakan nilai/angka yang merepresentasikan besaran/kuantitas pencemar yang diemisikan ke atmosfer oleh suatu aktivitas. Nilai ini dapat dinyatakan dalam massa pencemar per unit berat, volume, jarak atau durasi suatu aktivitas mengemisikan pencemar tersebut. Angka faktor ini berasal dari nilai rata-rata statistik dari data pemantauan yang tersedia, yang umumnya diasumsikan telah merepresentasikan nilai rata-rata jangka panjang untuk suatu kategori sumber pada aktivitas/fasilitas yang spesifik.

\section{3. HASIL DAN PEMBAHASAN}

\subsection{Penentuan Distribusi Beras}

Data yang digunakan untuk menentukan rute distribusi beras yang optimal adalah data permintaan beras pada setiap pasar tradisional di Kota Bandung sebanyak 27 pasar yang tersebar di 18 Kecamatan dengan kapasitas angkut 150 karung/hari. Data permintaan beras ditunjukkan pada Tabel 6 .

Hasil solver Matlab pada penelitian sebelumnya dengan menggunakan tarif angkutan barang berdasarkan The Asia Foundation 2008 yaitu sebesar USD 0,34/km, nilai tukar Rp 14.385/dollar, dan jarak antar titik menggunakan aplikasi google maps menghasilkan total jarak tempuh sebesar $549,09 \mathrm{~km} /$ hari $^{(13)}$. Penelitian ini menggunakan parameter yang sama dan mengubah kapasitas angkut menjadi dua skenario baru yaitu memaksimalkan muatan maksimum pada truk jenis fuso bak menjadi 160 karung/truk dan mencari jenis truk baru dengan maksimum muatan angkut 9 ton atau 180 karung/truk. Hasil perhitungan ditunjukkan pada Tabel 7 .

Tabel 6. Data permintaan beras ${ }^{(10)}$

\begin{tabular}{ccc}
\hline No & Nama Pasar Tradisional & $\begin{array}{c}\text { Permintaan } \\
\text { (karung/hari) }\end{array}$ \\
\hline 1 & Andir & 150 \\
2 & Ciroyom & 150 \\
3 & Anyar & 107 \\
4 & Pagarsih & 107 \\
5 & Cijerah & 450 \\
6 & Cihapit & 49 \\
7 & Gempol & 49 \\
8 & Sukahaji & 57 \\
9 & Leuwipanjang & 265 \\
10 & Cihaurgeulis & 220 \\
11 & Cikaso & 334 \\
12 & Pamoyanan & 146 \\
13 & Jatayu & 146 \\
14 & Sadang Serang & 204 \\
15 & Tilil & 204 \\
16 & Cicadas & 136 \\
17 & Kiaracondong & 136 \\
18 & Cicaheum & 136 \\
19 & Palasari & 220 \\
20 & Ciwastra & 238 \\
21 & Karapitan & 126 \\
22 & Kota Kembang & 126 \\
23 & Sederhana & 335 \\
24 & Gegerkalong & 127 \\
25 & Sarijadi & 127 \\
26 & Kosambi & 57 \\
27 & Ujungberung & 238 \\
\hline & Total & 4.640 \\
\hline & &
\end{tabular}

Tabel 7. Hasil pengolahan data

\begin{tabular}{cccccc}
\hline $\begin{array}{c}\text { Sistem } \\
\text { Distribusi }\end{array}$ & $\begin{array}{c}\text { Kapasitas } \\
\text { Angkut } \\
\text { (karung/Truk) }\end{array}$ & $\begin{array}{c}\text { Total } \\
\text { Jarak } \\
\text { (km/hari) }\end{array}$ & $\begin{array}{c}\text { Kendaraan yang } \\
\text { digunakan } \\
\text { (kendaraan/hari) }\end{array}$ & $\begin{array}{c}\text { Rata-rata Jarak } \\
\text { Tempuh } \\
\text { (km/kendaraan/hari) }\end{array}$ & $\begin{array}{c}\text { Total Biaya } \\
\text { Transportasi } \\
\text { (per tahun) }\end{array}$ \\
\hline $\begin{array}{c}\text { Pengiriman } \\
\text { Langsung }\end{array}$ & 150 & 627,60 & 40 & 15,69 & Rp 41.069 .529 \\
$\begin{array}{c}\text { Pengiriman } \\
\text { Berbagi }\end{array}$ & 150 & 549,09 & 34 & 16,15 & Rp 34.038 .039 \\
$\begin{array}{c}\text { Pengiriman } \\
\text { Berbagi }\end{array}$ & 160 & 548,40 & 32 & 17,1375 & Rp 33.137 .064 \\
$\begin{array}{c}\text { Pengiriman } \\
\text { Berbagi }\end{array}$ & 180 & 490,00 & 28 & 17,5 & Rp 29.045.915 \\
\hline
\end{tabular}


Tabel 7 menunjukkan total biaya transportasi per tahun yang paling minimum sebesar Rp29.045.915,00 maka rute yang dipilih adalah sistem pengiriman berbagi dengan kapasitas angkut maksimum 9 ton atau 180 karung per hari dengan 28 kendaraan per hari dan rata-rata jarak tempuh $17,5 \mathrm{~km}$ per kendaraan per hari. Berikut adalah rutenya yang ditunjukkan pada Tabel 8 .

Tabel 8. Rute distribusi pada skenario pengiriman berbagi (180 karung)

\begin{tabular}{|c|c|c|}
\hline $\begin{array}{c}\text { Kendaraan } \\
\text { ke- }\end{array}$ & Rute & $\begin{array}{c}\text { Jarak } \\
\text { Tempuh (km) }\end{array}$ \\
\hline 1 & $1-12-1$ & 5,6 \\
\hline 2 & $1-6-1$ & 7,6 \\
\hline 3 & $1-11-5-1$ & 9,5 \\
\hline 4 & 1-7-1 & 7,6 \\
\hline 5 & 1-8-13-1 & 12,2 \\
\hline 6 & $1-4-10-23-1$ & 22 \\
\hline 7 & $1-2-21-1$ & 23,7 \\
\hline 8 & $1-19-1$ & 10,2 \\
\hline 9 & $1-32-9-1$ & 17,6 \\
\hline 10 & 1-3-1 & 8,8 \\
\hline 11 & $1-28-25-1$ & 22,4 \\
\hline 12 & 1-33-1 & 16,8 \\
\hline 13 & $1-27-1$ & 12 \\
\hline 14 & $1-18-1$ & 12,8 \\
\hline 15 & $1-24-15-1$ & 21,9 \\
\hline 16 & 1-34-1 & 16,8 \\
\hline 17 & $1-37-39-30-1$ & 36,5 \\
\hline 18 & 1-31-1 & 9,4 \\
\hline 19 & $1-16-1$ & 18,4 \\
\hline 20 & $1-17-1$ & 18,4 \\
\hline 21 & $1-20-1$ & 21,4 \\
\hline 22 & $1-26-1$ & 22,2 \\
\hline 23 & $1-22-1$ & 19 \\
\hline 24 & $1-38-1$ & 32,2 \\
\hline 25 & $1-35-1$ & 22,6 \\
\hline 26 & $1-36-1$ & 22,6 \\
\hline 27 & $1-14-1$ & 19,6 \\
\hline \multirow[t]{2}{*}{28} & $1-29-1$ & 20,2 \\
\hline & Total & 490 \\
\hline
\end{tabular}

\subsection{Analisis Emis Gas Buang}

Analisis perhitungan beban emisi kendaraan dengan cara menghitung terlebih dahulu volume kendaraan per tahun dan panjang perjalanan per tahunnya seperti yang ditunjukkan pada Tabel 9. Beban emisi kendaraan untuk setiap unsur gas buang yang dihasilkan truk yang ditunjukkan pada Tabel 10.

Berikut adalah contoh perhitungan nilai gas buang $\mathrm{CO}$ pada Tabel 10 untuk pengiriman berbagi (150 karung) berdasarkan Tabel 9.
$\mathrm{E}=12.410$ kendaraan/tahun $\mathrm{x}$ 5.894,65 $\mathrm{km} / \mathrm{kendaraan} / \mathrm{tahun} \times 8,4 \mathrm{~g} / \mathrm{km} \times 10^{-6}$
$\mathrm{E}=1,684$ ton/tahun

Berdasarkan hasil perhitungan emisi gas buang pada keempat skenario, dapat disimpulkan bahwa semakin jauh jarak tempuh maka akan berbanding terbalik dengan jumlah kendaraan, semakin jauh jarak tempuh akan berbanding terbalik dengan jumlah gas buang yang dihasilkan, dan semakin rendah jumlah kendaraan akan berbanding lurus dengan jumlah gas buang yang dihasilkan seperti yang ditunjukkan pada Gambar 3. Artinya jika tujuannya untuk menurunkan jumlah gas buang maka strateginya adalah mengatur jumlah kendaraan minimum melalui peningkatan kapasitas angkut per kendaraan walaupun jarak tempuh per kendaraanya lebih panjang. Tren ini terlihat juga pada Tabel 7 yang menunjukkan semakin sedikit jumlah kendaraan akan semakin jauh jarak tempuh per kendaraanya namun jika dikalikan, akan menghasilkan total jarak tempuh dengan tren menurun seperti yang ditunjukkan pada Gambar 4.

Tabel 9. Data jarak tempuh dan jumlah kendaraan per tahun

\begin{tabular}{|c|c|c|}
\hline $\begin{array}{l}\text { Sistem } \\
\text { Distribusi }\end{array}$ & $\begin{array}{l}\text { Rata-rata Jarak } \\
\text { Tempuh } \\
\text { (km/kendaraan } \\
\text { /tahun) }\end{array}$ & $\begin{array}{c}\text { Jumlah } \\
\text { Kendaraan } \\
\text { (kendaraan/ } \\
\text { tahun) }\end{array}$ \\
\hline $\begin{array}{l}\text { Pengirman } \\
\text { Langsung } \\
\text { (150 karung) }\end{array}$ & $\begin{array}{c}15,69 \times 365= \\
5.726,85\end{array}$ & $\begin{array}{c}40 \times 365= \\
14.600\end{array}$ \\
\hline $\begin{array}{l}\text { Pengiriman } \\
\text { Berbagi } \\
\text { (150 karung) }\end{array}$ & $\begin{array}{c}16,15 \times 365= \\
5.894,65\end{array}$ & $\begin{array}{c}34 \times 365= \\
12.410\end{array}$ \\
\hline $\begin{array}{l}\text { Pengiriman } \\
\text { Berbagi } \\
\text { (160 karung) }\end{array}$ & $\begin{array}{c}17,1375 \times 365= \\
6.255,187\end{array}$ & $\begin{array}{c}32 \times 365= \\
11.680\end{array}$ \\
\hline $\begin{array}{l}\text { Pengiriman } \\
\text { Berbagi } \\
\text { (180 karung) }\end{array}$ & $\begin{array}{c}17,5 \times 365= \\
6.387,5\end{array}$ & $\begin{array}{c}28 \times 365= \\
10.220\end{array}$ \\
\hline
\end{tabular}

Tabel 10. Hasil perhitungan emisi gas buang

\begin{tabular}{ccccc}
\hline $\begin{array}{c}\text { Komposisi Gas } \\
\text { Buang }\end{array}$ & $\begin{array}{c}\text { Pengirman } \\
\text { Langsung } \\
\text { (150 karung) }\end{array}$ & $\begin{array}{c}\text { Pengiriman } \\
\text { Berbagi } \\
\text { (150 karung) }\end{array}$ & $\begin{array}{c}\text { Pengiriman } \\
\text { Berbagi } \\
(\mathbf{1 6 0} \text { karung) }\end{array}$ & $\begin{array}{c}\text { Pengiriman } \\
\text { Berbagi } \\
\text { (180 karung) }\end{array}$ \\
\hline $\mathrm{CO}$ (ton/tahun) & 1,924 & 1,684 & 1,681 & 1,502 \\
$\mathrm{HC}$ (ton/tahun) & 0,412 & 0,361 & 0,360 & 0,322 \\
$\mathrm{NO}$ (ton/tahun) & 4,055 & 3,547 & 3,543 & 3,166 \\
$\mathrm{PM} 10$ (ton/tahun) $_{\mathrm{CO}_{2} \text { (ton/tahun BBM) }}$ & 0,321 & 0,281 & 0,280 & 0,250 \\
$\mathrm{SO}_{2}$ (ton/tahun) & 726,623 & 635,725 & 634,927 & 567,312 \\
\hline
\end{tabular}




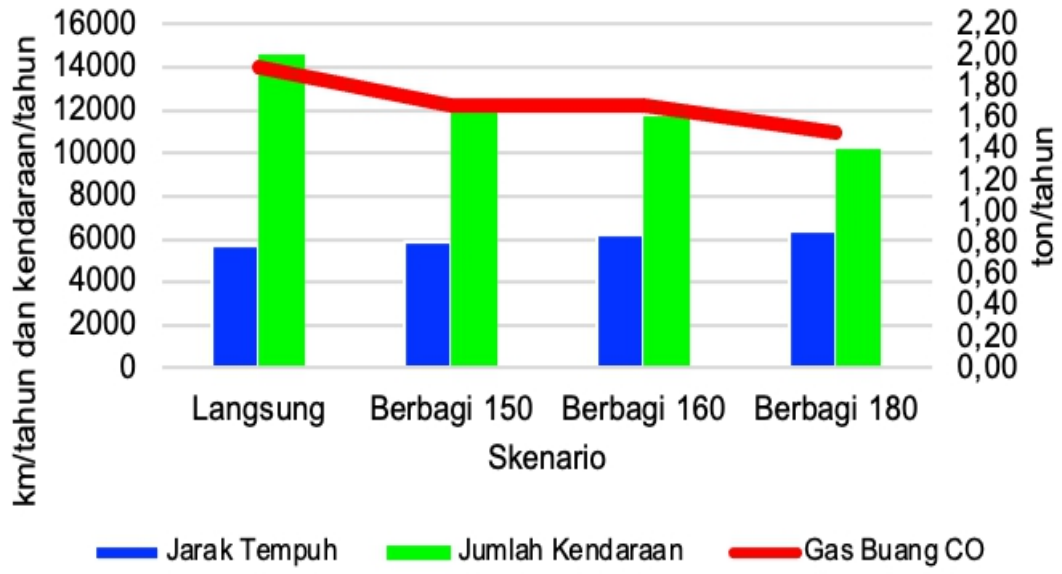

Gambar 3. Hubungan beban emisi CO terhadap jarak tempuh dan jumlah kendaraan per tahun

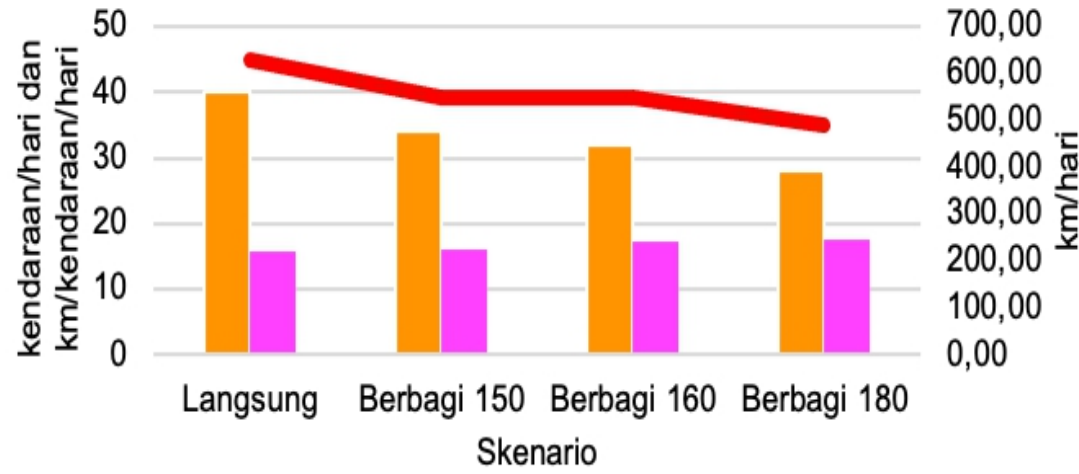

Jumlah Kendaraan $\quad$ Jarak per kendaraan $\quad$ Total Jarak Tempuh

Gambar 4. Hubungan total jarak tempuh terhadap jumlah kendaraan dan jarak tempuh per kendaraan per hari

\section{KESIMPULAN}

Berdasarkan hasil dan pembahasan, menurunkan emisi gas buang dilakukan dengan cara mengatur jumlah kendaraan dan total jarak tempuh minimum melalui peningkatan kapasitas angkut dan sistem distribusi pengiriman berbagi. Pada sistem distribusi pengiriman langsung dengan kapasitas angkut 150 karung per hari dan total jarak tempuh $627,6 \mathrm{~km}$ per hari menunjukkan total emisi gas buang CO 1,924 ton/tahun; $\mathrm{HC} 0,412$ ton/tahun; $\mathrm{NO}_{x} 4,055$ ton/th; $\mathrm{PM}_{10} 0,321$ ton/tahun; $\mathrm{CO}_{2} 726,632$ ton/tahun BBM; dan $\mathrm{SO}_{2}$ 0,188 ton/tahun. Melalui strategi sistem distribusi pengiriman berbagi dengan peningkatan kapasitas angkut menjadi 180 karung per hari dan total jarak tempuh $490 \mathrm{~km}$ per hari, total emisi gas buang CO 1,502 ton/tahun; $\mathrm{HC} 0,322$ ton/tahun; $\mathrm{NO}_{\times} 3,166$ ton/th; $\mathrm{PM}_{10} 0,250$ ton/tahun; $\mathrm{CO}_{2} 567,312$ ton/tahun BBM; dan $\mathrm{SO}_{2} 0,147$ ton/tahun. Strategi tersebut dapat menurunkan emisi gas buang sebesar $21,92 \%$ untuk setiap komposisinya.

\section{DAFTAR PUSTAKA}

1 Yudi, S.W.S. (2017), Emisi Kendaraan Pada Ruas Jalan Provinsi Di Jawa Barat, J. HPJI, vol. 3, no. 1, pp. 29-36.

2 Kemenkumham. (2016), Pengesahan Paris Agreement To The United Nations Framework Convention On Climate Change, Undang Undang No 16 Tahun 2016.

3 Kusumaningtyas, S. D. A., Aldrian, E., Wati, T., Atmoko, D., \& Sunaryo. (2018), The recent state of ambient air quality in Jakarta Aerosol Air Qual. Res., vol. 18, no. 9, pp. 2343-2354.

4 Bappenas. (2014), Pedoman Teknis Perhitungan Baseline Emisi Gas Rumah Kaca Sektor Berbasis Energi.

5 Pemprov Jabar. (2012), Peraturan Gubernur Jawa Barat No. 56 Tahun 2012 Tentang Rencana Aksi Daerah Penurunan Emisi Gas Rumah Kaca (RAD-GRK) Provinsi Jawa Barat.

6 Setijadi. (2015), Penerapan Green Logistics: untuk Menghadapi MEA 2015, Supply Chain Indones., Accessed: Feb. 02, 2020. [Online]. Available:

https://supplychainindonesia.com/penerapangreen-logistics-untuk-menghadapi-mea-2015/.

7 BPS Kota Bandung. (2018), Jumlah Kendaraan Bermotor Jenis Truck dan Pickup, (2018).

8 Sudarwanto, W., Utami, I. W., Asmoro, R., \& 
Wulandari, A. (2020), Bahaya Emisi Gas Buang Kendaraan Berbahan Bakar Di Perkotaan, Semin. Nas. HUBISINTEK 2020, pp. 101-105.

9 Posciety Health. (2018), STOP Pembakaran Hidrokarbon! Dampaknya Sangat Buruk Bagi Kesehatan \& Lingkungan, posciety.com, Accessed: Feb. 05, 2020. [Online]. Available: https://www.posciety.com/dampak-

pembakaran-hidrokarbon-bagi-lingkungan-dankesehatan/.

10 Saragih, N. I., \& Rachman, R. S. (2020), The Application of Vehicle Routing Problem for Rice Distribution System in City of Bandung,Atl. Press, vol. 160, pp. 334-338.

11 Sugiarti. (2015), Gas Pencemar Udara dan Pengaruhnya Bagi Kesehatan Manusia, J. Chem., pp. 50-58.

12 Sianipar, M., Fu'ani, D., Sutopo, W., \& Hisjam, M. (2017), PENENTUAN RUTE KENDARAAN MENGGUNAKAN METODE CLARK AND WRIGHT SAVING HEURISTIC (STUDI KASUS: PT. SINAR SOSRO), PERFORMA Media IIm. Tek. Ind., vol. 16, no. 2, pp. 143151.

13 Sopandi, Deryl, B., Dicka, A., Diki, P., Uswatun, H.T., \& Saragih, N. I. (2020), Application of Improved Nearest Neighbor Heuristic to Solve Vehicle Routing Problem for Rice Distribution System in Bandung, Solid State Technol., vol. 63, no. 4, [Online]. Available:
http://solidstatetechnology.us/index.php/JSST/ article/view/3285.

14 Kementerian Lingkungan Hidup dan Kehutanan RI. (2012), Peraturan Menteri Negara Lingkungan Hidup Nomor 12 Tahun 2012 Tentang Pedoman Perhitungan Beban Emisi Kegiatan Industri Minyak dan Gas Bumi.

15 RAD,A. S. T. \& GÜLMEZ, S.Y.S. (2017), Green Logistics for SustainabiliSürdürülebilirllilçinYeşiLojistik Özet, Int. J. Manag. Econ. Bus., vol. 13, no. 3, pp. 603-614.

16 Andriansyah. (2015), Manajemen Transportasi Dalam Kajian dan Teori."

17 Miro, F. (2005), Perencanaan Transportasi untuk Mahasiswa, Perencana, dan Praktisi.

18 UUD RI (2009), Undang Undang Republik Indonesia No 32 Tahun 2009 Tentang Perlindungan dan Pengelolaan Lingkungan Hidup.

19 Kementerian Lingkungan Hidup Dan Kehutanan Republik Indonesia (2020), Peraturan Menteri Lingkungan Hidup Dan Kehutanan Republik Indonesia Nomor 14 Tahun 2020 Tentang Indeks Standar Pencemar Udara.

20 Aldrian, E., Kurniawan, E., \& SDA, K. (2014), Layanan Kualitas Udara dari Hujan Asam Hingga Gas Rumah Kaca, Puslitbang BMKG, p. 170. 